\title{
Effect of some Environmental Factors on the Distributions and Chlorophyll Contents of Fresh Water Phytoplankton of the River Nile before El- Qanater El-Khairia Barrage, Egypt.
}

\author{
H.A. Mansour", A.M. Shaaban, and A.A. Saber, \\ Botany Department, Faculty of Science, Ain Shams University, \\ Abbasia, Cairo, Egypt.
}

\begin{abstract}
T NVESTIGATIONS were carried out on the seasonal variations, biodiversity and chlorophyll contents of phytoplankton in relation to physico-chemical parameters of the River Nile water before ElQanater El-Khairia barrage during two successive years (from summer 2006 to spring 2008). The detected phytoplankton community consisted of 176 species in 62 genera of six systematic algal divisions. Chlorophyta (42.05\%) recorded the highest population followed by Bacillariophyta $(40.91 \%)$, Cyanophyta $(9.65 \%)$ and Euglenophyta $(5.11 \%)$. Pyrrophyta and Xanthophyta were less dominant. Chlorophyta, Bacillariophyta and Cyanophyta were responsible for the remarkable fluctuations in the phytoplanktonic picture of the investigated water. The highest number of taxa of all divisions was recorded in summer 2006. These may due to the highest recorded values in $\mathrm{K}^{+}, \mathrm{Cl}^{-}, \mathrm{NO}_{3}^{-}$, and $\mathrm{PO}_{4}^{-3}$ with lowest values in the electrical conductivity (E.C), total dissolved salts (TDS), $\mathrm{HCO}_{3}{ }^{-}$and $\mathrm{CO}_{3}{ }^{2-}$ during this season. Algal productivity (as number of individuals $\mathrm{L}^{-1}$ ) attained its highest value during summer 2007, while its lowest value was recorded in winter 2008. These may correlated to the highest recorded values of temperature, silicate and bicarbonate in association with complete depletion in Phosphorus and Carbonate values in the same season. The lowest number of taxa and the total algal productivity (as number of individuals $\mathrm{L}^{-1}$ ) of all divisions were recorded during winter 2008. This was positively correlated with the relative increased in Sulphate, Carbonate, Magnesium and Phosphate concentrations during winter 2008. This may attribute to death and decomposition of aquatic microorganisms in this season. Summer 2006 showed maximum values in both Shannon-Weaver diversity $(H)$ and species richness (D). There more or less positive correlations between the fluctuations of total chlorophyll contents $\left(\mathrm{ug} \mathrm{L}^{-1}\right)$ and those of total number of individuals $\left(\mathrm{L}^{-1}\right)$ of the studied phytoplankton.
\end{abstract}

Keywords: Fresh water phytoplankton, Physico-chemical parameters, Algal chlorophyll contents, Diversity, Shannon's index.

Inland water bodies attracted the attention of various workers to study water quality and distribution of phytoplankton from time to time, (Ratha et al., 2003). Aquatic algae (particularly phytoplankton) are the major primary producers, the most diverse and ubiquitous organisms in many aquatic systems. They plays an

*Corresponding author: rodynarwan@yahoo.com 
important role in maintaining the biological balance and quality of water due to their rapidly responds to changes in the aquatic environment (Shehata et al., 1997; Pandey et al., 1998 and Wolfram et al., 2007). Phytoplankton biomass constitutes a bio-monitoring index; however the productivity of an aquatic environment is directly corrected with the density of phytoplankton (Sobhy, 2008; Elewa et al., 2009; Benarjee and Narasimha, 2013). Shannon-Weaver index values are biotic indices which reflect the characteristics of a phytoplankton community; however studies using number of species alone cannot describe community properties adequately (Mulder et al., 2001 and Weis et al., 2007). Chlorophyll in algae is vital to photosynthesis and for the survival of them in planet. Conventionally biologists and ecologists consider chlorophyll as a reliable and world-wide standard algal biomass index (Knefelkamp et al., 2007; Shehata et al., 2008 and Boyce et al., 2010). Counting and volume assessment of cells and measurement of pigment concentration are widely used to estimate algal biomass (Smayda, 1978 and Jeffrey et al., 1997). The relationship between chlorophyll a and phytoplankton biomass has been widely studied (Tolstoy, 1979; Vörös and Padisák, 1991; Jones et al., 1996 and Rolland et al., 2010).

However Chlorophyll a is common to all photosynthetic organisms and it is relatively easy and rapid to quantify (Wetzel and Likens, 2000). The objective of this study was to investigate the diversity, species composition, seasonal succession and total chlorophyll contents of phytoplankton in relation to physicochemical parameters in the main branch of the River Nile water before El-Qanater El-Khairia barrage during two successive years (from summer 2006 to spring 2008), to establish basic knowledge that can be used for the aquatic management.

\section{Material and Methods}

\section{Study area}

Fresh water study region was located before El-Qanater El-Khairia barrage at $30^{\circ} 11^{`} 38^{\prime \prime} \mathrm{N}$ and $31^{\circ} 07^{\prime} 54^{\prime \prime} \mathrm{E}$. However El Kanater El Khairia is one of the major cities El Qalyubiya Governorate in the north of Cairo (Egypt). The barrages are $16 \mathrm{~km}$ north of Cairo and are located on the Nile just before it splits to form the Damietta and Rosetta (or Rashid) branches.

\section{Samples collection}

Water samples were collected periodically (by filtering water in $15 \mu \mathrm{m}$ mesh plankton net.) from the studied barrage every season during two successive years (from summer 2006 to spring 2008). Water samples from the candidate region were held in ice boxes in form of three parts (part for physicochemical analysis, second water part was preserved with 5\% formalin and used for the biological and counting of phytoplankton and the last water part for the analysis of total chlorophyll contents). All water samples were immediately transported to the laboratory for the physicochemical, biological and total chlorophyll analysis as well as for the counting of phytoplankton.

Egypt. J. Bot., Vol. 55, No. 1 (2015) 


\section{Physicochemical analysis}

Temperature (air and surface water) was recorded on the spot using centigrade thermometer. $\mathrm{pH}$ of the water sample was measured by using the gun $\mathrm{pH}$ meter on the spot. Physicochemical analysis of the electrical conductivity (EC), the total dissolved salts (T.D.S.) and the major equivalent percentages (e \%) of cations, anions, phosphate, nitrate, nitrite and silicate of the candidate water sample $(300 \mathrm{~mL})$ were done according to standard methods (APHA, 1998). Moreover the results of cations and anions were represented graphically by bar diagrams according to Klimentov, (1983).

\section{Biological analysis and Counting of phytoplankton}

Some of the preserved water sample was used to investigate the phytoplankton taxa under microscope (MICRO Star ${ }^{\circledR}$ AO Scientific Instruments) which were identified with the help of standard references of Zabelina et al. (1951); Gollerbach et al. (1953); Hendey (1964); Patrick and Reimer (1966 and 1975); Philipose (1967); Jensen (1985) and Faust and Gulledge (2002). In the another preserved water sample (about 50 liters of surface water), algal organisms were allowed to settle out in the measuring cylinders for 5 days. The supernatant liquid was then carefully withdrawn. The settled organisms were tipped into $250 \mathrm{ml}$ beakers and again allowed to sink for 2 days. By so doing, it is possible to reduce the algal residue to $10 \mathrm{ml}$. According to Sourina (1981), after shaking from $10 \mathrm{ml}$ concentrated material, an aliquot was withdrawn by a pipette and loaded into a Max Levy counting chamber haemocytometer. The results of algal count were expressed as number of individuals per liter.

\section{Shannon-Weaver biodiversity index and Species richness}

Shannon-Weaver diversity of phytoplankton was carried out using the method of Shannon and Weaver (1949). The mathematical equation for Shannon-Weaver index $(\mathrm{H})$ is: $=-\Sigma(\mathrm{ni} / \mathrm{N}) \ln (\mathrm{ni} / \mathrm{N})$. Where, (ni) is the abundance of species $\mathrm{i}$, and $(\mathrm{N})$ is the total number of individuals in the community. The Species richness (D) has also been used according to Margalef (1968).

The mathematical equation for species richness is: $\mathrm{D}=\frac{\mathrm{s}-1}{\mathrm{inN}}$

Where, $(\mathrm{D})=$ species richens, $(\mathrm{S})=$ the number of species in the population and $\mathrm{N}=$ total number of individuals in the population.

Total chlorophyll (ug $\left.L^{-1}\right)$ analysis

Total chlorophyll was extracted by dimethyl sulfoxide (DMSO) according to Burnison (1980). The extracted solution was measured by reading the absorbance (A) of the pigment extract spectrophotometrically (PERKIN-ELMER LAMBDA 2 UV/VIS) at $666 \mathrm{~nm}$ and calculated (ug L ${ }^{-1}$ ) according to Seely et al. (1972). Total chlorophyll $\left(\mathrm{ug} \mathrm{L}^{-1}\right)=\mathrm{A} \times \mathrm{C} \times \mathrm{F}$ $\mathrm{A}=$ reading at $666 \mathrm{~nm} .,(\mathrm{F})=11.3$ (factor). $(\mathrm{C})=$ volume of extract $/$ sample volume. 


\section{Physicochemical Analysis}

\section{Results}

The physical characteristics of the studied water present in Table 1 and Fig. 1 revealed that, water temperature ranged between $16^{\circ} \mathrm{C}-30^{\circ} \mathrm{C}$ in summer 2007 and winter 2008 respectively. $\mathrm{pH}$ values of water were fluctuated from around neutral $(\mathrm{pH}=7.10)$ in spring 2008 to relatively high alkaline value $(\mathrm{pH}=9.45)$ in autumn 2006. TDS were found in the same trend of the EC.However the higher values of EC and TDS were recorded during spring 2008 (0.56 mmhos/cm and $358.4 \mathrm{ppm}$ respectively). Whereas the lower values were showed during summer 2006 (0. $30 \mathrm{mmhos} / \mathrm{cm}$ and $192.0 \mathrm{ppm}$ respectively).Chemically, $\mathrm{Na}^{+}$cation was the highest in the composition of equivalent percents (e \%) during the all studied seasons, except in autumn 2007 when $\mathrm{Ca}^{++}$was the most dominant one (its concentration was $51.70 \%) . \mathrm{K}^{+}$was the minor cation, except in summer 2006 $(9.16 \%)$. However, $\mathrm{Mg}^{++}$was varied from $(16.57 \%$ to $42.63 \%)$ in spring 2008 and in winter 2007 respectively. With the reference to concentrations of major anions, the variability in their concentrations was also irregular with disappearance of carbonate during the all periods of study, except throughout spring 2007 and winter 2008 (11.28\% and $4.95 \%$, respectively). Bicarbonate attained the $1^{\text {st }}$ rank of the anionic composition of water throughout all seasons (its concentrations varied from $4.46 \%$ in summer 2006 to $78.93 \%$ in summer 2007). During summer 2006, chloride occupied the dominant one (55.67\%). Additionally, nitrite concentrations were relatively low and completely disappeared in spring 2008. Also, phosphate was not recorded in summer 2007.Whereas nitrate showed highest value $(0.74 \%)$ in summer 2006 and lowest value $(0.19 \%)$ in spring 2008 . Data dealing with silicate concentrations showed that the highest and lowest values $(1.70 \%$ and $0.10 \%)$ were detected during summer and winter 2007, respectively.

According to bar diagrams (Fig. 1), summer 2006 (I) showed sodium chloride and magnesium sulphate character; autumn 2006 (II) showed magnesium bicarbonate, sodium sulphate character; winter 2007 (III) had magnesium bicarbonate, sodium sulphate and calcium bicarbonate salts character. Sodium-magnesium bicarbonate and sodium sulphate constituted the third water type during spring 2007 (IV). In summer 2007 (V) water had magnesium-calcium-sodium bicarbonate salty character. Autumn 2007 (VI) characterized by magnesium-calcium bicarbonate salts. Moreover, winter 2008 (VII) showed magnesium bicarbonate, sodium sulphate and calcium bicarbonate salts characters. Lastly, spring 2008 (VIII) showed calcium-sodium-magnesium bicarbonate and sodium sulphate salty properties.

\section{B-Biological Analysis}

The detected phytoplankton community (Table 2, Fig. 2) composed 176 algal taxa which related to 62 genera and belonging to six systematic algal divisions. Chlorophyta was the dominant division accounted for $(42.05 \%)$ of total algal taxa, followed by Bacillariophyta (40.91\%), Cyanophyta (9.65\%) and Euglenophyta $(5.11 \%)$. Pyrrophyta and Xanthophyta were less dominant. 
TABLE 1. Seasonal variations in the physicochemical parameters of water during two successive years (from summer 2006 to spring 2008). T.D.S. = Total Dissolved Salts and E. C= Electrical conductivity.

\begin{tabular}{|c|c|c|c|c|c|c|c|c|c|c|c|c|c|c|c|c|}
\hline \multirow[b]{2}{*}{ Seasons } & \multirow[b]{2}{*}{$\left({ }^{\circ} \mathrm{C}\right)$} & \multirow[b]{2}{*}{ pH } & \multirow{2}{*}{$\begin{array}{c}\mathbf{E C} \\
\left(\begin{array}{c}\text { mmhos } \\
/ \mathbf{c m})\end{array}\right.\end{array}$} & \multirow{2}{*}{$\begin{array}{l}\text { I.D.S } \\
\text { ppm }\end{array}$} & \multicolumn{12}{|c|}{ e\% = equivalent percentage } \\
\hline & & & & & $\mathbf{N a}^{+}$ & $\mathbf{K}^{+}$ & $\mathrm{Ca}^{2+}$ & $\mathbf{M g}^{2+}$ & $\mathrm{Cl}^{-}$ & $\mathrm{SO}_{4}{ }^{2-}$ & $\mathrm{HCO}_{3}^{-}$ & $\mathrm{CO}_{3}^{2-}$ & $\mathrm{NO}_{3}{ }^{-}$ & $\mathrm{NO}_{2}^{-}$ & $\mathrm{PO}_{4}{ }^{3-}$ & $\mathrm{SiO}_{2}$ \\
\hline $\begin{array}{c}\text { Summe } \\
2006\end{array}$ & 24 & 8.33 & 0.30 & 192.0 & 47.99 & 9.16 & 17.95 & 24.91 & 55.76 & 22.30 & 4.46 & 0.00 & 0.74 & 0.01 & 16.73 & \\
\hline $\begin{array}{c}\text { Autumn } \\
2006\end{array}$ & 21 & 9.45 & 0.48 & 307.2 & 47.92 & 3.18 & 13.45 & 35.45 & 18.80 & 17.04 & 59.40 & 0.00 & 0.25 & 0.01 & 4.51 & \\
\hline \begin{tabular}{|c|} 
Winter \\
2007
\end{tabular} & 16 & 8.70 & 0.36 & 230.4 & 30.30 & 3.90 & 28.57 & 37.23 & 12.28 & 23.10 & 57.60 & 0.00 & 0.29 & 0.01 & 1.04 & \\
\hline \begin{tabular}{|c|} 
Spring \\
2007
\end{tabular} & 23 & 9.15 & 0.33 & 211.2 & 55.79 & 3.86 & 8.61 & 31.75 & 8.95 & 21.79 & 56.03 & 11.28 & 0.39 & 0.04 & 1.56 & \\
\hline $\begin{array}{c}\text { Summer } \\
2007\end{array}$ & 30 & 8.55 & 0.34 & 217.6 & 36.60 & 2.13 & 26.38 & 34.89 & 9.70 & 11.04 & 78.93 & 0.00 & 0.33 & 0.007 & 0.00 & 1. \\
\hline $\begin{array}{c}\text { Autumn } \\
2007\end{array}$ & 18 & 7.45 & 0.33 & 211.2 & 9.06 & 1.13 & 51.70 & 38.11 & 2.77 & 6.23 & 76.12 & 0.00 & 0.69 & 0.003 & 14.19 & 1. \\
\hline \begin{tabular}{|c|} 
Winter \\
2008
\end{tabular} & 17 & 8.81 & 0.44 & 281.6 & 40.48 & 4.02 & 12.87 & 42.63 & 17.71 & 26.04 & 50.0 & 4.95 & 0.26 & 0.01 & 6.73 & 0. \\
\hline \begin{tabular}{|c|} 
Spring \\
2008
\end{tabular} & 22 & 7.10 & 0.56 & 358.4 & 43.43 & 4.29 & 35.71 & 16.57 & 15.36 & 14.40 & 63.72 & 0.00 & 0.19 & 0.00 & 6.33 & 0.45 \\
\hline
\end{tabular}

TABLE 2. Total algal distribution and seasonal variations in the number of taxa of different algal divisions.

\begin{tabular}{|c|c|c|c|c|c|c|c|c|c|c|c|c|c|c|c|c|c|c|c|}
\hline \multirow{2}{*}{ Seasons } & \multicolumn{8}{|c|}{$\mathbf{1}^{s t}$ studied year } & \multicolumn{8}{|c|}{$2^{n d}$ studied year } & \multirow{2}{*}{\multicolumn{3}{|c|}{$\begin{array}{r}\text { Total algal } \\
\text { distribution }\end{array}$}} \\
\hline & \multicolumn{2}{|c|}{$\underset{2006}{\text { Summer }}$} & \multicolumn{2}{|c|}{$\begin{array}{c}\text { Autumn } \\
2006\end{array}$} & \multicolumn{2}{|c|}{$\begin{array}{c}\text { Winter } \\
2007\end{array}$} & \multicolumn{2}{|c|}{$\begin{array}{c}\text { Spring } \\
\mathbf{2 0 0 7}\end{array}$} & \multicolumn{2}{|c|}{$\begin{array}{c}\text { Summer } \\
2007\end{array}$} & \multicolumn{2}{|c|}{$\underset{2007}{\text { Autumn }}$} & \multicolumn{2}{|c|}{$\begin{array}{c}\text { Winter } \\
2008\end{array}$} & \multicolumn{2}{|c|}{$\begin{array}{c}\text { Spring } \\
2008\end{array}$} & & & \\
\hline Algal divisions & $\begin{array}{l}\text { Alg } \\
\text { tax: }\end{array}$ & al $\%$ & $\begin{array}{l}\text { Alg } \\
\text { tax }\end{array}$ & al $\%$ & & $\begin{array}{l}\text { gal } \\
\text { xa \% }\end{array}$ & $\begin{array}{l}\text { Alg } \\
\text { tax }\end{array}$ & $\begin{array}{l}\text { gal } \\
\text { a \% }\end{array}$ & $\begin{array}{l}\text { Alg } \\
\text { taxa }\end{array}$ & all & $\begin{array}{l}\text { Alge } \\
\text { tax }\end{array}$ & $\%$ & & al $\%$ & & al $\%$ & \begin{tabular}{|l|} 
Algal \\
taxa
\end{tabular} & \begin{tabular}{|l|} 
Algal \\
genera
\end{tabular} & $\%$ \\
\hline Cyanophyta & 10 & 9.71 & 10 & 15.38 & 13 & 20.63 & 10 & 10.53 & 10 & 10.53 & 9 & 13.04 & 9 & 16.07 & 9 & 12.16 & 17 & 10 & 9.65 \\
\hline Bacillariophyta & 43 & 41.75 & 23 & 35.38 & 23 & 36.51 & 33 & 34.74 & 44 & 46.32 & 29 & 42.03 & 18 & 32.14 & 32 & 43.24 & 72 & 22 & 40.91 \\
\hline Xanthophyta & & & & & & & 1 & 1.05 & & & & & & & 1 & 1.35 & 1 & 1 & 0.57 \\
\hline Pyrrophyta & 2 & 1.94 & 3 & 4.62 & 2 & 3.17 & 3 & 3.16 & 2 & 2.11 & 1 & 1.45 & 2 & 3.57 & 3 & 4.05 & 3 & 3 & 1.70 \\
\hline Euglenophyta & 6 & 5.83 & 2 & 3.08 & 1 & 1.59 & 4 & 4.21 & 4 & 4.21 & 1 & 1.45 & & & 4 & 5.41 & 9 & 2 & 5.11 \\
\hline Chlorophyta & 42 & 40.78 & 27 & 41.54 & 24 & 38.10 & 44 & 46.32 & 35 & 36.84 & 29 & 42.03 & 27 & 48.21 & 25 & 33.78 & 74 & 24 & 42.05 \\
\hline Total & 103 & 100.00 & 65 & 100.00 & 63 & 100.0 & 95 & 100.00 & 95 & 100.00 & 69 & 100.000 & 56 & 100.00 & 74 & 100.00 & 176 & 62 & 100.00 \\
\hline
\end{tabular}

Egypt. J. Bot., Vol. 55, No. 1 (2015) 

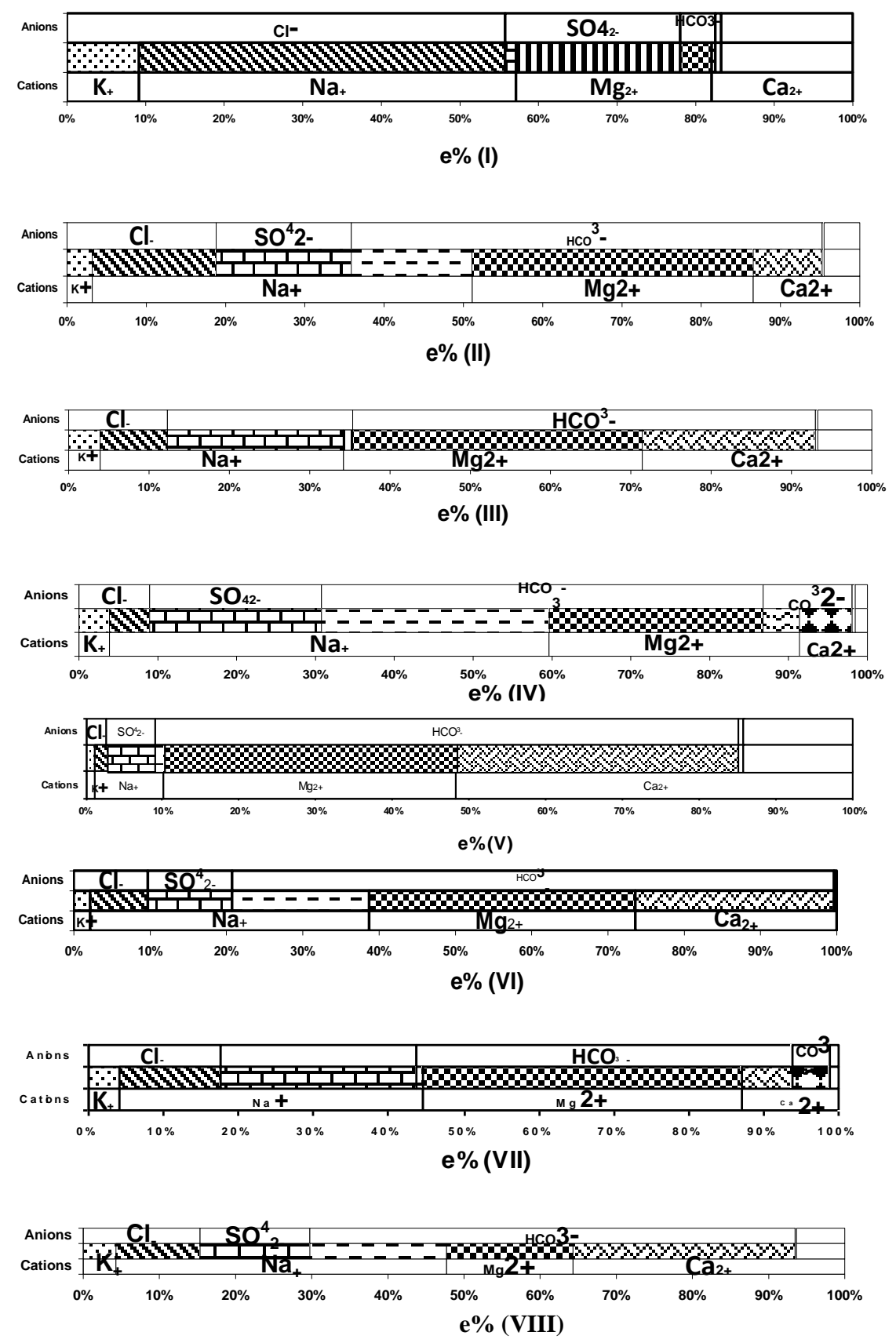

Fig. 1. Bar diagram for the analysis of water during Summer 2006 (I), Autumn 2006 (II),Winter 2007 (III), Spring 2007 (IV), Summer 2007 (V), Autumn 2007 (VI), Winter 2008 (VII) and Spring 2008 (VIII) seasons.

Egypt. J. Bot., Vol. 55, No. 1 (2015) 


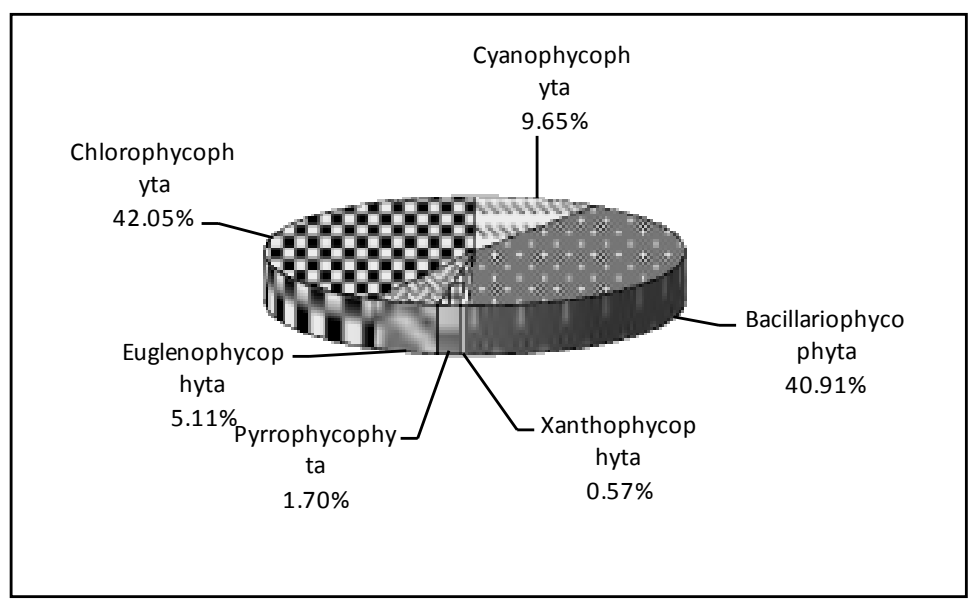

Fig. 2. Qualitative percentages of the different algal divisions

The highest number of taxa of all divisions was recorded in summer 2006 (103 algal taxa) and the lowest one was showed during winter 2008 (56 algal taxa). Cyanophyta (Table 2) was present in high numbers of taxa during winter 2007 (13 algal taxa) while the minimum recorded taxa were observed in autumn 2007, winter and spring 2008. With respect to diatoms, they reached their highest species diversity in both summer seasons 2006 and 2007 (43 and 44 algal taxa, respectively). Xanthophyta represented by Heterothrix quadrata that appeared only in spring seasons. Peridinium cinctum was recorded in all investigated seasons, followed by Ceratium hirrundinella. Concerning euglenoids, Euglena gracilis was observed in most studied seasons. However, there were no members related to this division in winter 2008. The maximum number of Chlorophyta was recorded in spring 2007 (44 taxa, Table 2) while the minimum ones were detected in winter 2007 (24 taxa).

Quantitatively, the algal productivity (as number of individuals $\mathrm{L}^{-1}$ ) present in Table 3, attained its highest value during summer 2007 (11774.300 individuals $\mathrm{L}^{-1}$ ), while the lowest value was recorded in winter 2008 (590.800 individuals $\mathrm{L}^{-1}$ ). Summer 2007 showed Chloro-Bacillario-Cyano-character. This was chiefly due to the overgrowth of Pediastrum simplex var. doudenarium, Dictyosphaerium pulchellum, Coelastrum scabrum and Staurastrum paradoxum (from green algae); Synedra ulna var. danica, Melosira granulata, Melosira granulata var. angustissima and Cyclotella ocellata (from diatoms) and Microcystis aeruginosa, Merismopedia punctata and Microcystis aeruginosa f. flos aquae (from blue green algae). The $2^{\text {nd }}$ type of quantitatively phytoplanktonic character was green algae-diatoms-character which recorded during summer 2006, autumn 2007 and winter 2008.The organisms responsible for this appearance were Dictyosphaerium pulchellum, Scenedesmus quadricauda, Staurastrum paradoxum, Coelastrum scabrum, Pediastrum simplex var. doudenarium, 
Errerella bornhemiensis, Actinastrum hantzschii, Selenastrum minutum and Sphaerocystis schroeteri (from green algae) and Cyclotella ocellata, Synedra ulna var. danica, Melosira granulata and Fragilaria construens (from diatoms).

In autumn 2006 and in spring seasons 2007 and 2008, Chloro-Cyanocharacter was detected, due to the contribution of some members of blue green algae in the main bulk of productivity, besides the green algal taxa, such as Pseudoholopedia convoluta, Merismopedia punctata, Microcystis firma, M. aeruginosa, Gomphosphaeria aponina and Microcystis aeruginosa f. flos aquae. Winter 2007 characterized by blue green-green algae-character. This could be attributed to the higher growth of blue green algae, especially Synechocystis pevalekii and the quantitative decrease in individuals or complete disappearance of some green algal taxa.

TABLE 3. Seasonal variations in total number of individuals $\left(x 10^{6} \mathrm{~L}^{-1}\right)$ of taxa of different algal divisions, the total chlorophyll contents, Shannon-Wiener diversity indices $(\mathrm{H})$, and species richness $(\mathrm{D})$ of the phytoplankton.

\begin{tabular}{|l|c|c|c|c|c|c|c|c|}
\hline $\begin{array}{l}\text { Seasons } \\
\text { Algal } \\
\text { Divisions }\end{array}$ & $\begin{array}{c}\text { Summer } \\
\mathbf{2 0 0 6}\end{array}$ & $\begin{array}{c}\text { Autumn } \\
\mathbf{2 0 0 6}\end{array}$ & $\begin{array}{c}\text { Winter } \\
\mathbf{2 0 0 7}\end{array}$ & Spring 2007 & $\begin{array}{c}\text { Summer } \\
\mathbf{2 0 0 7}\end{array}$ & $\begin{array}{c}\text { Autumn } \\
\mathbf{2 0 0 7}\end{array}$ & $\begin{array}{c}\text { Winter } \\
\mathbf{2 0 0 8}\end{array}$ & $\begin{array}{c}\text { Spring } \\
\mathbf{2 0 0 8}\end{array}$ \\
\hline Cyanophyta & 1.199 & 1.0739 & 1.7736 & 1.5627 & 1.9988 & 0.5591 & 0.1391 & 1.5041 \\
\hline Bacillariophyta & 3.0283 & 0.3587 & 0.7019 & 0.7665 & 2.3308 & 1.0144 & 0.2086 & 0.7823 \\
\hline Xanthophyta & & & & 0.0233 & & & & 0.0349 \\
\hline $\begin{array}{l}\text { Pyrrophyta } \\
\text { Euglenophyta }\end{array}$ & 0.2998 & 0.1497 & 0.0498 & 0.0699 & 0.3998 & 0.0199 & 0.0098 & 0.1047 \\
\hline $\begin{array}{l}\text { Chlorophyta } \\
\text { Total number of } \\
\text { individuals ( N ) } \\
\text { L }^{-1}\end{array}$ & 9.4222 & 3.5294 & 3.9228 & 6.7602 & 11.7743 & 3.3803 & 0.5908 & 5.5029 \\
\hline $\begin{array}{l}\text { Total chlorophyl } \\
\text { contents } \\
\text { (ug L } \text { - }^{-1}\end{array}$ & 35.75 & 2.02 & 0.83 & 6.96 & 21.19 & 0.68 & 0.52 & 3.95 \\
\hline (H) & 5.63 & 4.71 & 4.72 & 5.05 & 4.69 & 4.04 & 4.91 & 4.77 \\
\hline (D) & 6.35 & 4.24 & 4.08 & 5.98 & 5.77 & 4.52 & 4.14 & 4.70 \\
\hline
\end{tabular}

\section{C- Shannon-Weaver Biodiversity Index and Species Richness}

Data related to Shannon-weaver diversity index (Table 3) showed that the main branch of the River Nile before El-Qanater El-Khairia barrage reached its highest phytoplanktonic species diversity in summer season $2006(\mathrm{H}=5.63)$, whereas the lowest value $(H=4.04)$ was detected in autumn 2007. The best species richness of the main branch of the River Nile before El-Qanater ElKhairia barrage was recorded in summer $2006(D=6.35)$, whereas the lowest one was in winter $2007(\mathrm{D}=4.08)$. 


\section{D- Total Chlorophyll Contents of Phytoplankton}

Total chlorophyll contents of phytoplankton during all periods of study (Fig 3) showed that, the highest total chlorophyll amount $\left(35.75 \mathrm{ug} \mathrm{L}^{-1}\right)$ was recorded in summer 2006, while the lowest one $\left(0.52 \mathrm{ug} \mathrm{L}^{-1}\right)$ was detected in the algal collection of winter 2008. In general, total chlorophyll of the phytoplankton of the studied fresh water region were reached their highest amounts during two summer seasons 2006 and 2007 (35.75 and $21.19 \mathrm{ug} \mathrm{L}^{-1}$ respectively). This was in the same trend of the detected total number of individuals $\mathrm{L}^{-1}$. On the other hand, autumn and winter seasons characterized by low amounts of total chlorophyll.

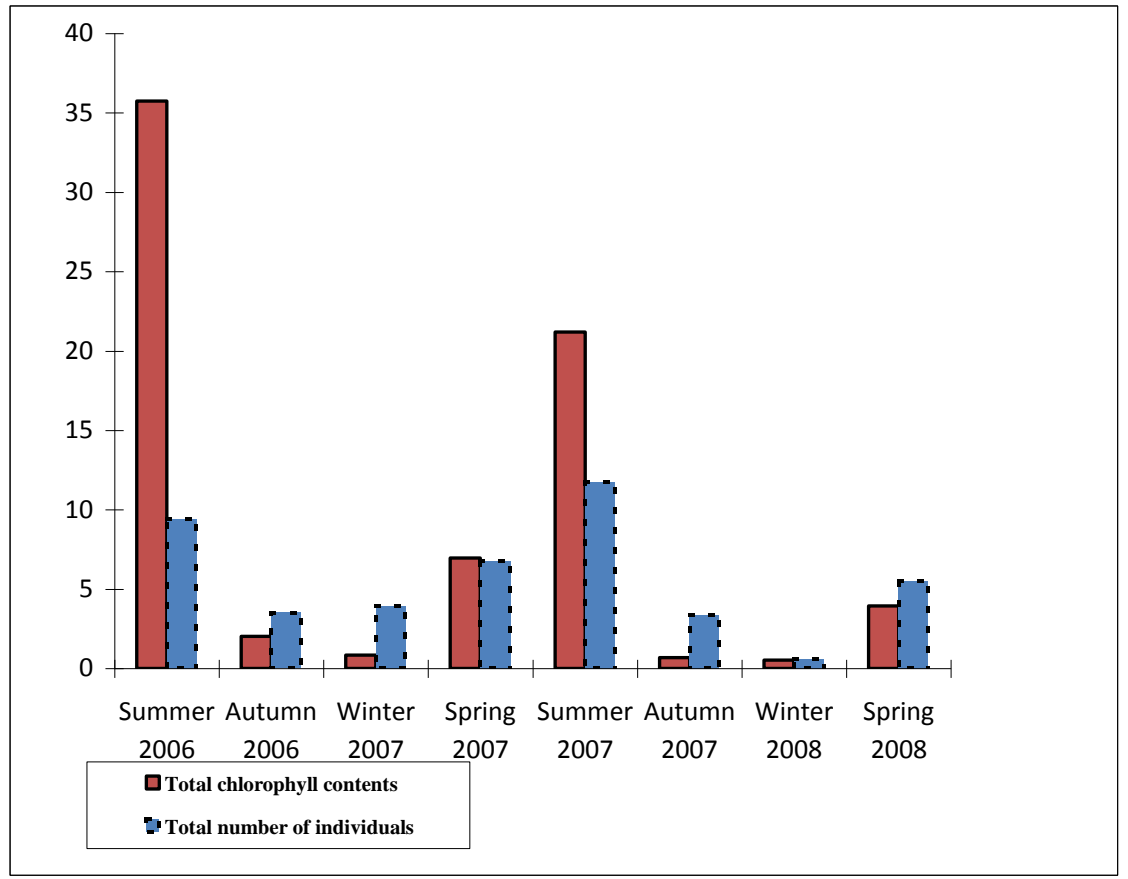

Fig. 3. Correlation between total chlorophyll contents (ug $\left.L^{-1}\right)$ and total number of individuals $\left(\mathbf{L}^{-1}\right)$.

\section{DISCUSSION}

Due to the short life cycles of phytoplankton, the algal species composition and diversity is known to change seasonally in response to changes in physical, chemical and biological conditions of the water (Reynolds, 1984; Solanki, 2013). Hence their standing crop and species composition indicate the quality of the water mass in which they are found (Ishaq and Khan, 2013). The current qualitative results showed that, the detected phytoplankton community composed 176 algal taxa which related to 62 genera and belonging to six systematic algal 
divisions. Chlorophyta was the dominant algal group, followed by Bacillariophyta, Cyanophyta and Euglenophyta. Pyrrophyta and Xanthophyta were less dominant. These were positively correlated to the neutral to alkaline nature of the studied water .By referring to this observation, a similar picture has been reported by Gharib (2006), Mishra et al. (2009) and Ishaq and Khan (2013) who pointed out that the members of Chlorophyta and Bacillariophyta are more characteristic of the neutral to alkaline conditions.

The greatest number of taxa of all divisions was recorded in summer 2006 (103 algal taxa). These were positively correlated to the highest recorded values in $\mathrm{K}^{+}$, $\mathrm{Cl}^{-}, \mathrm{NO}_{3}^{-}$, and $\mathrm{PO}_{4}^{-3}$ with lowest values in E.C, TDS, $\mathrm{HCO}_{3}^{-}$and $\mathrm{CO}_{3}{ }^{2-}$ during summer 2006 (Table 1). Since, under the highest level of potassium, the growth and photosynthesis of algae usually become rich (Cole, 1983). In addition, Phosphate, nitrate and chloride contents play a vital role in algal distributional pattern (Ishaq and Khan, 2013).

Current study also showed positive correlation between the dominance of euglenoides (number of individuals $\mathrm{L}^{-1}$ ) and with the highest contents of $\mathrm{NO}_{3}^{-}$ and $\mathrm{PO}_{4}{ }^{-3}$ in association with the lowest content of $\mathrm{HCO}_{3}{ }^{-}$during summer 2006 (Salman et al, 2013 ). The highest extensive growth of total individuals of all algal divisions was recorded in summer 2007 (11774.300 individuals $\left.\mathrm{L}^{-1}\right)$.This season had Chloro-Bacillario-Cyano-character with magnesium-calcium-sodium bicarbonate salty feature. These may correlated to the highest recorded values of temperature, silicate and bicarbonate with complete depletion in phosphorus and carbonate in the same season.

In accordance with this result, Rajagopal et al, (2010) and Schabhuttl et al, (2013) who pointed out that higher water temperature is considered to be one of the most important factors in the productivity and periodicity of the phytoplankton standing crop, the distribution and seasonal variations of floating algae as well as the chemical and physical characteristics of water. El-Hadad, 2005 and Abdo et al., 2010 who also stated that, the complete depletion in phosphorus and carbonate contents during summer season may be attributed to the flourishing of phytoplankton and the increase in the photosynthetic process. Moreover, blue green algae assimilate phosphate at a faster rate and accumulate large amount of reserve phosphate for extended growth periods at low phosphate concentration. Meanwhile, Okbah and El- Gohary (2002) stated that, the decomposition and death of diatom, in addition to the increase of generation rate from underlying sediments are the factors influencing silicate concentration.

The seasonal variations in numbers of individuals $\left(\mathrm{L}^{-1}\right)$ of three quantitatively major divisions (Chlorophyta, Bacillariophyta and Cyanophyta) were responsible for the remarkable fluctuations in the phytoplanktonic picture of the investigated water (Abdel-Satar, 2005 and Ishaq and Khan, 2013). Quantitatively, Chlorophyta dominated over other recorded divisions, where the highest productivity (number of individuals $\mathrm{L}^{-1}$ ) of them was showed during summer 2007 and 2006 
respectively. These were positively correlated with EC and T.D.S values those classified the studied water under the fresh water category (Freeze and Cherry 1979 and Jakhar, 2013).

In accordance with these results, Rajagopal et al., (2010) who reported that, Chlorophyta are a large and important group of freshwater algae. Moreover the current results revealed that, the lowest number of taxa and the total algal productivity (as number of individuals $\mathrm{L}^{-1}$ ) of all divisions were recorded during winter 2008 (56 algal taxa and 590.800 individuals $\mathrm{L}^{-1}$ respectively). This was positively correlated with the relative increased in sulphate, carbonate, magnesium and phosphate concentrations during winter 2008 which may attribute to death and decomposition of aquatic microorganisms (El-Hadad, 2006 and Abdo et al., 2010).

Shannon-Weave biodiversity index has been used to estimate community biodiversity broadly (Guo et al., 2010). The Shannon-Weaver index values of phytoplankton in the studied region showed little variation among seasons. This suggesting that, overall of phytoplankton species richness and diversity were quite stable all year round (Khuantrairong and Traichaiyaporn, 2008). The maximum values of both Shannon-Weaver diversity $(H)$ and species richness (D) were recorded in summer 2006. These suggesting the strongest ecological health status of the main branch of the River Nile before El-Qanater El-Khairia barrage during this season. Shannon-Weaver index values (varied from 4.04 to 5.63) of phytoplankton communities during all the studied seasons were more than 3 .

Therefore the water quality of the studied region should be classified as clean water. This was in agreement with Whitton, (1975) and Hooper et al., (2005) who stated that, a high diversity value suggests a healthier ecosystem and a low diversity value a less healthy or degraded one. The reduction in numbers of species and the increase in number of individuals that characterize polluted areas results in significant decreases in values of diversity. The sharp decline in species richness (D) in winter 2007 is likely due to the highest numbers of cyanophytes taxa (13 taxa) and their slightly highest number of individuals (1773.6 individuals $\mathrm{L}^{-1}$ ) during this season (Khuantrairong and Traichaiyaporn, 2008).

Data of total chlorophyll were reached their highest amounts during two summer seasons. This was in the same trend of the detected total number of individuals (11774.300 and 9.4222 individuals $\mathrm{L}^{-1}$ in summer 2007 and 2006 respectively). Autumn and winter seasons characterized by low amounts of total chlorophyll. These observed more or less positive correlations between the fluctuations of total chlorophyll contents $\left(\mathrm{mg} \mathrm{L}^{-1}\right)$ and those of total number of individuals per liter (Wetzel and Likens, 2000 and Rolland et al., 2010). 


\section{References}

Abdel-Satar, A. M. (2005) On the water quality of Lake Bardawil, Egypt. J. Egypt Acad. Soc. Environ. Develep., (D- Environmental studies), b, 1: 49-73.

Abdo, M.H., Sabae, S. Z., Haroon, B.M., Refaat, B.M. and Mohammed, A.S. (2010) Physico-Chemical characteristics, microbial assessment and antibiotic susceptibility of pathogenic bacteria of Ismailia Canal Water, River Nile, Egypt. Journal of American Science, 6, (5) $234-250$.

APHA. (1998) "Standard Methods for the Examination of Water and Wastewater", $20^{\text {th }}$ ed. American Public Health Association, Washington, DC.

Benarjee, G. and Narasimha, R.K. (2013) Physico-chemical factors influenced plankton biodiversity and fish abundance- a case study of Nagaram tank of Warangal, Andhra Pradesh. International Journal of Life Sciences Biotechnology and Pharma Research, 2, 2: 248-260.

Boyce D.G., Lewis M.R. and Worm B. (2010) Global phytoplankton decline over the past century, Nature, 466: 591-596.

Burnison, B. K. (1980) Modified dimethyl sulfoxide (DMSO) extraction for chlorophyll analysis of phytoplankton. Can .J. Fish. Aquat. Sci., 37: 729-733.

Cole, A.G. (1983) “Text Book of Limnology". $3^{\text {rd }}$ ed., C.V. Mosby Co., London, pp: 401.

El-Haddad, E.S.M. (2005) Some environmental studies on water and sediment of Ismailia canal from El-Mazalat to Anshas region. Thesis for Master degree, Fac. of Sci. Al Azhar Univ.

Elewa, A.A., Shehata, M.B., Mohamed, L.F., Badr, M.H. and Abdel Aziz, G.S. (2009) Water quality characteristics of the River Nile at Delta Barrage with special reference to rosetta Branch. Global J. Environ. Research, 3 (1): 1-6.

Faust, M.A. and Gulledge, R.A. (2002) Identifying harmful marine dinoflagellates. Smithsonian Institution. Contributions from the United States National Herbarium, 42: 1-144.

Freeze, R.A. and Cherry, J.A. (1979) Groundwater. In: "Hydrogeology: Principles and Practice" (2005). Hiscock, K. M. (Ed.), Blackwell Science Ltd Pub., 74-121 pp.

Gharib, S.M. (2006) Effect of freshwater flow on the succession and abundance of phytoplankton in Rosetta estuary, Egypt. Internat. J. of Oceans and Oceangr., 1, (2) 207-225.

Gollerbach, M.M., Kosinckaja, E. K. and Polanskii, V. I. (1953) "Freshwater algae of USSR", 2. Cyanophyta. Pub. "Sov. Nauke" Moscow, 652 pp.

Guo, Q., Ma, K., Yang, L., Cai, Q. and He, K. (2010) A comparative study of the impact of species composition on a freshwater phytoplankton community using two contrasting biotic indices. Ecological Indicators, 10: 296-302.

Egypt. J. Bot., Vol. 55, No. 1 (2015) 
Hendey, N.I. (1964) "An Introductory Account of the Smaller Algae of British Coastal Waters". Part V. Bacillariophyceae (Diatoms). London. Her Majetys Staionery Office Pub., 317 pp.

Hooper, D.U., Chapin, F.S., Ewell, J.J., Hector, A., Inchausti, P. and Lavorel, S. (2005) Effects of biodiversity on ecosystem functioning: a consensus of current knowledge. Ecol. Monogr., 75, 3-35.

Ishaq, F. and Khan, A. (2013) Comparative assessment of physico-chemical conditions and Plankton diversity of River Tons and Asan in Dehradun District of Uttarakhand. Advances in Applied Science Research, 4, (2) 342-355.

Jakhar, P. (2013) Role of phytoplankton and zooplankton as health indicators of aquatic ecosystem: A review. Int. J. of Innovative Res. and Studies, 2, 12: 489- 500.

Jeffrey, S. W., Mantoura, R. F. C. and Wright, S. W. (1997) "Phytoplankton Pigments in Oceanography: Guidelines to Modern Methods". Unesco, Paris.

Jensen, N. G. (1985) The Pennate Diatoms. A translation of Hustedt's "Die Kieselalgen, 2. Teil." Koeltz Scientific Books, Koenigstein, 918 pp.

Jones, R.I., Young, J.M., Hartley, A.M. and Bailey-Watts, A.E. (1996) Light limitation of phytoplankton development in a oligotrophic lake-Loch Ness, Scotland. Freshwater Biol., 35: 533-543.

Khuantrairong, T. and Traichaiyaporn, S. (2008) Diversity and seasonal succession of the phytoplankton community in Doi Tao Lake, Chiang Mai Province, Northern Thailand. The Natural History Journal of Chulalongkorn University, 8, (2) 143-156.

Klimentov, P.P. (1983) “General Hydrogeology”, Mir . pub . Moscow . 239 PP.

Knefelkamp, B., Carstens, K. and Wiltshire, K.H. (2007) Comparison of different lter types on chlorophyll-a retention and nutrient measurements, J. Exp. Mar. Biol. Ecol., 345: 61-70.

Margalef, D.R. (1968) "Perspectives In Ecological Theories". University of Chicago Press, Chicago, 111 pp.

Mishra, R.k.; Shaw, B.P. and Sahu, B.K. (2009) Seasonal appearance of Chlorophyceae phytoplankton bloom by river discharge off Paradeep at Orissa coast in the Bay of Bengal. Envirn. Monit. Assess., 149: 261-273.

Mulder, C.P.H., Uliassi, D.D., Doak, D.F. (2001) Physical stress and diversityproductivity relationships: The role of positive interactions. Proc. Natl. Acad. Sci.U.S.A., 98: 6704-6708.

Okbah, M. and El-Gohary, S. (2002) Physical and chemical characteristics of Lake Edku Water, Egypt. Mediterr. Mar. Sci., 3, (2) 27-39.

Pandey, Ushapandey Tyagi, H.R., and Rai, N. (1998) Algal flora and physico chemical environment of Fateh saker lake, Phykos., 37,187: 29-30. 
Patrick, R. and Reimer, C. W. (1966) "The Diatoms of The United States" (Exclusive of Alaska and Hawaii). Vol. 1: Fragilariaceae, Eunotiaceae, Achnanthaceae and Naviculaceae. Monogrs. Acad. Sci. Philad. 13: 688 pp.

Patrick, R. and Reimer, C.W. (1975) "The Diatoms of The United States" (Exclusive of Alaska and Hawaii). Vol. 2, Part 1: Entomoneidaceae, Cymbellaceae, Gomphonemaceae and Epithemiaceae. Monogrs. Acad. Sci. Philad. 13: 213 pp.

Philipose, M.T. (1967) “Chlorococcales”. Indian Council of Agric. Res., New Delhi, 363 pp.

Rajagopal, T., Thangamani, A. and Archunan1, G. (2010) Comparison of physico chemical parameters and phytoplankton species diversity of two perennial ponds in Sattur area, Tamil Nadu. Journal of Environmental Biology, 31, 5: 787-794.

Ratha, S .K., Naik, K. and Padhi, S.B. (2003) Epiphytic algal diversity associated with different aquatic macrophytes of fresh water ponds in and around Berhampur university campus, Orissa, India. Nat. Env.and Poll. Tech., 2, (2) 205-208.

Reynolds, C. S. (1984) Phytoplankton periodicity: The interactions of form, function and environmental variability. Freshwater Biol., 14: 111-142.

Rolland, A. Rimet, F. and Jacquet, S. (2010) A 2-year survey of phytoplankton in the Marne Reservoir (France): A case study to validate the use of an in situspectrofluorometer by comparison with algal taxonomy and chlorophyll a measurements. Knowledge and Management of Aquatic Ecosystems, 398, 02.

Salman, J.M., Jawad, H.J., Nassar, A.J. and Hassan, F.M. (2013) A Study of Phytoplankton communities and related environmental factors in Euphrates river (between Two Cities: Al-Musayyab and Hindiya), Iraq. Journal of Environmental Protection, 4: 1071-1079.

Schabhuttl, S., Hingsamer, P., Weigelhofer, G., Hein, T., Weigert, A. and Striebel, S. (2013). Temprature and species richness effects in phytoplankton communities. Oecologia, 171, (2) 527- 536.

Seely, G.R., Duncan, M.J. and Widaver, W.E. (1972) Preparative and analytical extraction of pigments from brown algae with dimethyl sulfoxide. Mar. Biol., 12: 184-188.

Shannon, C. E. and Weaver, W. (1949) "The Mathematical Theory of Communications". Illinois Uni. Press, London, 125 pp.

Shehata, S.A.; Bader, S.A. and Wahba, S.Z. (1997) Phytoplankton composition of the River Nile at the intake of El-Giza water works (Egypt). J. Appl. Sci., 12(2): 389-412.

Shehata, S.A.; Ali, G.H. and Wahba, S.Z. (2008) Distribution pattern of Nile water algae with reference to its treatability in drinking water. J. App. Sci. Res., 4, (6) 722730. 
Smayda, T.J. (1978) From phytoplankters to biomass. In: "Phytoplankton Manual". Sournia, A. (Ed.), Unesco, Paris, pp. 273-279.

Sobhy, E. H. M. (2008) Phytoplankton of River Nile. In: "Final Report of Biodiversity of River Nile Project", Abd El-Karim, M.S. (Ed.)National Institute of Oceanography and Fisheries, Alexandria and Cairo. (in Arabic).

Solanki, H.A. (2013) Correlation of plankton diversity and density with physico-chemical parameters in Ghuma lake, rural area of Ahmedabad. Research scholar JJT. Uni. Rajasthan, 2, (7) 175 - 178.

Sourina, A. (1981) "Phytoplankton Manual”. Pub. Unit. Nat. Educ. Sci. and Cult. Organ. Paris. UNESCO, 334 pp.

Tolstoy, A. (1979) Chlorophyll a in relation to phytoplankton volume in some Swedish lakes. Arch.Hydrobiol., 85: 133-151.

Vörös, L. and Padisak, J. (1991) Phytoplankton biomass and chlorophyll a in some shallow lakes in central Europe. Hydrobiologia, 215: 111-119.

Weis, J. J., Cardinale, B. J., Forshay, K. J. and Ives, A. R. (2007). Effects of species diversity on community biomass production change over the course of succession. Ecology, 88: 929-939.

Wetzel R.G. and Likens G.E. (2000) "Limnological Analyses", 3 rd ed. Springer, London.

Whitton, B. A. (1975) “River ecology”. Blackwell scientific publications, London.

Wolfram, G., Dokulil M. T., Pall, K., Reichmann, M., Schulz, L., Argillier, C., de Bortoli, J., Martinez, P.J., Rioury, C., Hoehn, E., Riedmüller, U., Schaumburg, J., Stelzer, D., Buzzi, F., Dalmi, A., Morabito, G., Marchetto, A., Remec-Rekar, S. and Urbanic, G. (2007) "Intercalibration Exercise", Technical Report + Annexes, Alpine GIG (Lakes), Vienna - Ispra.

Zabelina, M.M., Kicelov, I.A., Proschkina-Laverenko, A.I. and Scheshykova, V.S. (1951) "The Freshwater Algae of USSR". Vol. 4. Bacillariophyta. Pub. "Sov. Nauke" Moscow, $619 \mathrm{pp}$.

(Received 10/6/ 2014; accepted 27/10/2014) 


\section{تأثير بعض العوامل البيئية على الإنتثار و محتوي الكلوروفيل

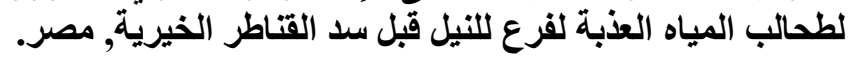 \\ هدي انور منصور ـ عبد السلام شعبان- عبد الله عنتر

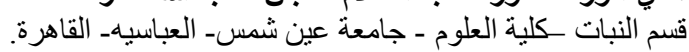

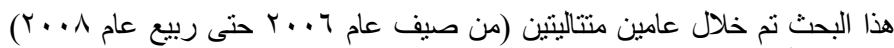

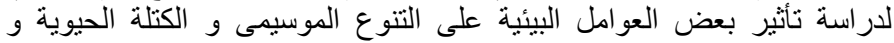

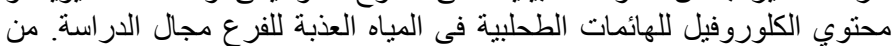

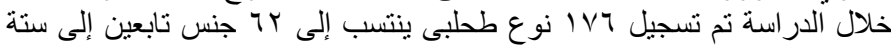

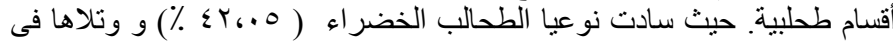

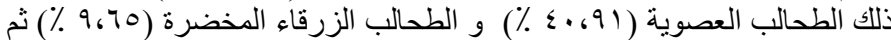

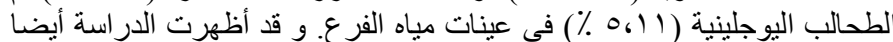

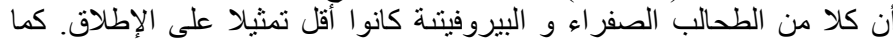

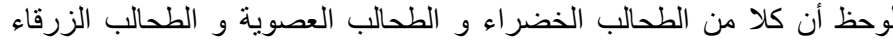

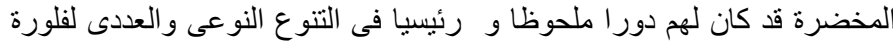

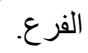

و سجلت النتائج أعلى عدد للوحدات الطحلبية على صعيد كل الأقسام

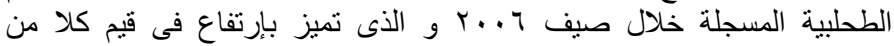

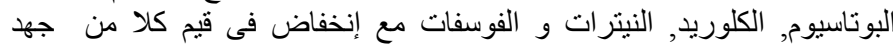

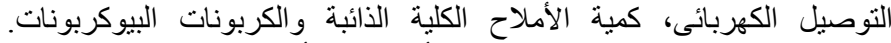

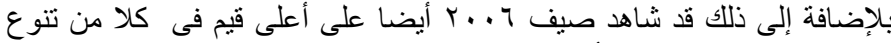

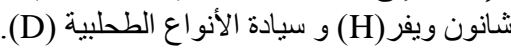

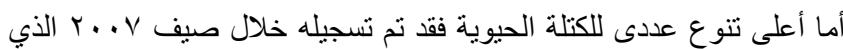

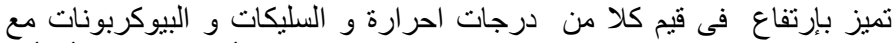

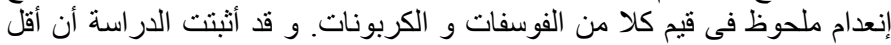

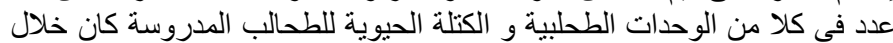

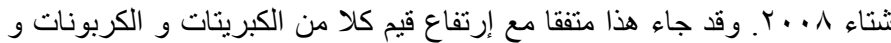

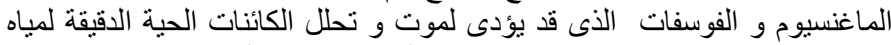

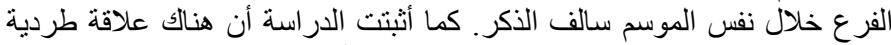
إلى حد ما بين الكمية الكلية لصبغة الكلوروفيل و ولفيل الأعداد الكلية للهائمات الطحلبية. 